Prof.dr hab.inż. Eugene Kossov

Instytut Naukowo-Badawczy Transportu Kolejowego, Moskwa

dr inz. Marek Babet

Politechnika Krakowska

\title{
Lokomotywy z silnikiem turbinowym
}

\begin{abstract}
W artykule przedstawiono zagadnienia celowości zastosowania silników turbinowych na środkach transportu, określono zadania, rozwiazanie których pozwoli zbudować lokomotywę nowego pokolenia z silnikiem turbinowym. Zaprezentowano obliczenia trakcyjne dla trzech wariantów lokomotyw z silnikiem turbinowym, opisano schemat perspektywicznego silnika turbinowego dla lokomotyw, przedstawiono charakterystyki porównawcze sprawności silników turbinowych i silnika wysokoprężnego lokomotyw, dokonano oceny wskaźników trakcyjnych i energetycznych perspektywicznych lokomotyw liniowych z silnikiem turbinowym.
\end{abstract}

Powrót do rozwiązań z lat poprzednich, w tym do zastosowania silników turbinowych (ST) na środkach transportu, jest procesem naturalnym, potwierdzonym przez historię rozwoju techniki. Można przytoczyć wiele przykładów, kiedy wspomniany powrót podyktowany był osiagnięciami ogólnego rozwoju technologii. W obecnym okresie, w porównaniu do lat 70-ch XX wieku, nastapiły duże zmiany. Powstały następujące okoliczności, potwierdzające celowość zastosowania ST w pojazdach.
1. Zużycie paliwa przez lokomotywę określane jest sprawnością zespołu napędowego, która to z kolei zależna jest od maksymalnej temperatury cyklu pracy silnika. Rozwój lotniczych ST i materiałów konstrukcyjnych pozwolił na znaczne podniesienie maksymalnie dopuszczalnej temperatury cyklu pracy w komorze spalania, $\mathrm{np}$. $\mathrm{w}$ 1960-1970-ch latach temperatura ta wynosiła $700-750^{\circ} \mathrm{C}$, a obecnie osiaga ona wartość $1700^{\circ} \mathrm{C}$. Oznacza to, że sprawność termiczna prostego cyklu ST może być zwiększona z 20 do $48 \%$. 
2. W sposób znaczący zmieniły się możliwości przemysłu elektrotechnicznego w zakresie budowy prądnic wysokoobrotowych, zapewnienia przekazania mocy od zespołu napędowego do kół, realizacji sterowania silnikiem i urządzeniami pomocniczymi. W chwili obecnej nie ma problemu $\mathrm{z}$ wykorzystaniem dowolnego pierwotnego źródła napędu dla realizacji siły pociągowej niezależnie od jego charakterystyk (zależność momentu i mocy od prędkości obrotowej).

3. W porównaniu do lat poprzednich znaczącej zmianie uległ na świecie stosunek społeczeństw do problemów ochrony środowiska. Normy emisji szkodliwych substancji do atmosfery, zwłaszcza tlenków azotu, stały się bardziej rygorystyczne. W omawianych ST emisje szkodliwych substancji do atmosfery na jednostkę wytworzonej energii są 10-15 razy mniejsze, niż dla silników spalinowych, przez co ich zastosowanie staje się coraz bardziej uzasadnione.

4. Znaczącą zaletą silnika turbinowego w porównaniu z innymi silnikami są jego wskaźniki dotyczące ciężaru i wymiarów gabarytowych. Ma to duże ogólne znaczenie dla transportu, a w szczególności przy organizacji ruchu pasażerskiego dużych prędkości.

5. Jednym $z$ ważnych czynników, wpływających na podjęcie decyzji o zastosowaniu ST, jest możliwość jego zasilania różnymi rodzajami paliw, w tym także gazem ziemnym. W tym przypadku jest to związane $z$ cena, jak i ze zmniejszeniem emisji szkodliwych substancji do atmosfery.

6. W zespole napędowym z ST nie jest wymagany układ chłodzenia nośników ciepła, co jest szczególnie ważne przy eksploatacji w niskich temperaturach. W tych warunkach zwiększają się sprawność i moc silnika turbinowego, a zmniejszają się koszty obsługi.

7. Niezmiernie ważnym czynnikiem przy zastosowaniu ST na środkach transportu jest pracochłonność obsługi i napraw w miejscu eksploatacji. Przy obsłudze silników turbinowych w warunkach lokomotywowni nie jest wymagany demontaż rewizyjny silnika, dlatego przy tworzeniu nowych linii znacznie zmniejszają się nakłady na infrastrukturę.

8. Producenci posiadają określone doświadczenie w zakresie budowy i eksploatacji wysokotemperaturowych wymienników ciepła dla realizacji złożonych cykli w ST. Sprawność silnika turbinowego $\mathrm{z}$ wymiennikiem - podgrzewaczem zwiększa się o 8-10\%, a przy mocach powyżej $4000 \mathrm{~kW}$ i umiarkowanej temperaturze w komorze spalania (1500K) może być o 2-8\% wyższa, niż dla nowoczesnego silnika spalinowego
(43\%). Zastosowanie dodatkowego chłodzenia międzystopniowego powietrza $\mathrm{W}$ sprężarce pozwala zwiększyć sprawność ST do $55 \%$ i więcej.

Wymienione osiagnięcia $\mathrm{w}$ rozwoju technologii pozwalają zbudować lokomotywy z silnikiem turbinowym (LST) o wysokich wskaźnikach technicznoekonomicznych. W tym celu należy rozwiązać szereg odpowiednich zadań, a mianowicie opracować i zbudować:

- specjalny silnik turbinowy dla lokomotyw z wymiennikiem - podgrzewaczem i dodatkowym chłodzeniem powietrza w sprężarce;

- wysokoobrotową prądnicę o odpowiedniej mocy, połączoną bezpośrednio (bez przekładni redukującej) z wałem ST;

- wyposażenie elektryczne, zapewniające realizację siły pociagowej z silnikami prądu przemiennego, zasilanie wszystkich urządzeń pomocniczych i sieci pokładowej z jednej prądnicy;

- odpowiedni zespół przetwornic (falowników trakcyjnych);

- układ sterowania, diagnostyki i bezpieczeństwa, zapewniający współpracę układów lokomotywy;

- zasobnik energii, włączony w obwód główny, w celu wykonywania manewrów lokomotywą, rekuperacji energii hamowania i stabilizacji warunków pracy ST;

- układ przechowywania i dawkowania skroplonego gazu ziemnego do silnika z układem zabezpieczenia przeciwpożarowego i przeciwwybuchowego.

Można skonstatować, że aktualnie dostępne są wszystkie niezbędne środki do rozwiązania problemów budowy lokomotyw z silnikami turbinowymi nowej generacji, znacznie różniących się od pojazdów budowanych w latach 70-ch zeszłego wieku.

W pierwszej kolejności należy ocenić, jaka powinna być moc lokomotywy na liniach kolejowych. Proponuje się wykorzystać pojęcia zunifikowanej masy pociagów towarowych $(6000 \mathrm{Mg})$, średniej prędkości technicznej $(47 \mathrm{~km} / \mathrm{h})$ i realnych profili linii kolejowych na odcinkach obsługi trakcyjnej. Skład wagonów o masie $6000 \mathrm{Mg}$ i długości $850 \mathrm{~m}$ zestawiony jest z 60 -u wagonów o masie $100 \mathrm{Mg}$ każdy.

Na rys. 1 przedstawiono charakterystyki trakcyjne lokomotyw z 12-a i 16-a osiami napędnymi, o nacisku $250 \mathrm{kN}$ na oś i mocy, odpowiednio, 5600 i 4900 $\mathrm{kW}$. Na ww. rysunku wykreślono także charakterystyki całkowitych oporów ruchu dla pociagu 6000 Mg na wzniesieniach 9, 11 i $15 \%$.

Lokomotywa z 12-a osiami nie może prowadzić pociagu o masie $6000 \mathrm{Mg}$ na wzniesieniu powyżej 11\%. Zwiększenie mocy trakcyjnej z 4900 do $5600 \mathrm{~kW}$ nie rozwiązuje problemu. Przy 16-u osiach napędnych do prowadzenia pociagu $6000 \mathrm{Mg}$ na 


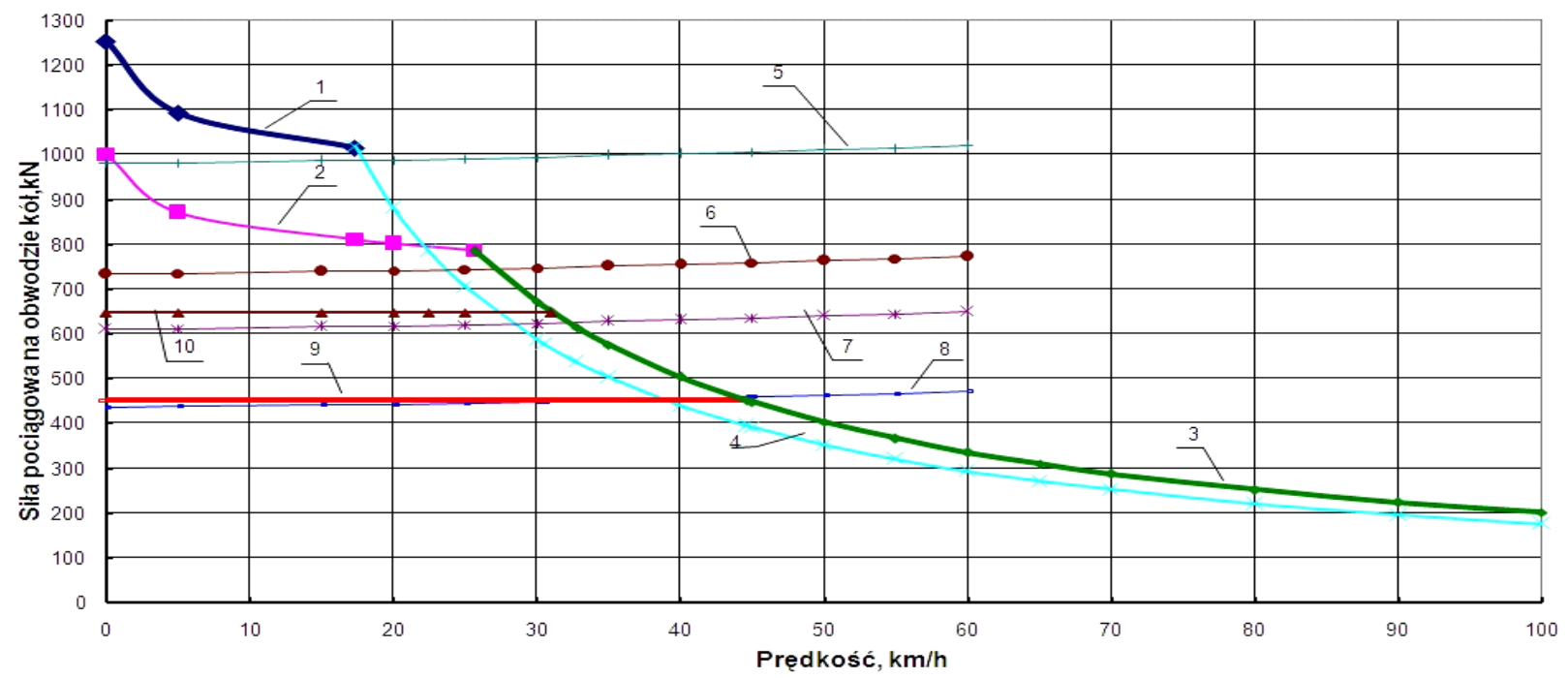

Rys. 1. Charakterystyki trakcyjne lokomotyw z silnikiem turbinowym LST1, LST2 i LST3

1 - ograniczenie przyczepności przy masie lokomotywy 376t (LST2, LST3); 2 - ograniczenie przyczepności przy masie lokomotywy 300Mg (LST1); 3 - siła pociągowa na obwodzie kół przy mocy 5600kW (LST1); 4 - siła pociagowa na obwodzie kół przy mocy 4900kW (LST2, LST3); 5,6,7- opory ruchu pociąu o masie $6000 \mathrm{Mg}$ na wzniesieniach odpowiednio 15, 11 i 9\%; 8 - opory ruchu pociagu o masie 4100Mg na wzniesieniu 9\%; 9 - ograniczenie siły pociagowej ciąłej lokomotywy LST1; 10 - ograniczenie przy prędkości $\mathrm{V}-31,1 \mathrm{~km} / \mathrm{h}$

wzniesieniu $15 \%$ wystarczy $4900 \mathrm{~kW}$, jednakże należy zapewnić siłę pociagową ciagłą $1000 \mathrm{kN}$ przy prędkości 17,5 km/h.

Obliczenia wykazują, że moc $4900 \mathrm{~kW}$ jest wystarczająca dla zapewnienia średniej prędkości technicznej $47 \mathrm{~km} / \mathrm{h}$ przy masie pociagu $6000 \mathrm{Mg}$ na wszystkich odcinkach obsługi trakcyjnej. Przy współczynniku wykorzystania mocy 0,82 zainstalowana moc silnika powinna wynosić $6000 \mathrm{~kW}$. Przy wyborze lokomotywy nowej generacji należy uwzględnić fakt, że silnik turbinowy przy wtrysku wody pozwala zwiększyć moc o $25-30 \%$ bez zmniejszenia sprawności. W tym przypadku moc silnika turbinowego może wynosić $4500 \mathrm{~kW}$.

Głównym zagadnieniem jest oczywiście budowa silnika turbinowego dla lokomotyw o mocy $6000 \mathrm{~kW}$. $\mathrm{Na}$ rys. 2 przedstawiono schemat ST dla lokomotyw opracowany przez Centralny Instytut Lotnictwa (CIAM) [1].

W silniku należy realizować złożony obieg termodynamiczny. Wentylator (2) tłoczy powietrze do silnika i do chłodnicy powietrza (5) za pierwszą (3) i drugą (20) sprężarką. Po sprężeniu w trzeciej sprężarce (17) powietrze ogrzewa się w wymienniku - podgrzewaczu (7) i przepływa do komory spalania (8). Turbina posiada trzy stopnie rozprężania. Pierwszy stopień (9) napędza sprężarki $(3,20,17)$. Dwa drugie stopnie $(10,11)$ napędzają wentylator $(2)$ i prą̧nicę (12). Wał sprężarek $(3,17,20)$ i turbiny (9) połączony jest $\mathrm{z}$ wałem wentylatora (2), turbiny $(10,11)$ i prądnicy (12) poprzez reduktor synchronizujący (21). Przewidziana jest możliwość przepuszczania powietrza pierwszego i drugiego stopnia sprężania przez wymienniki ciepła $(14,15)$

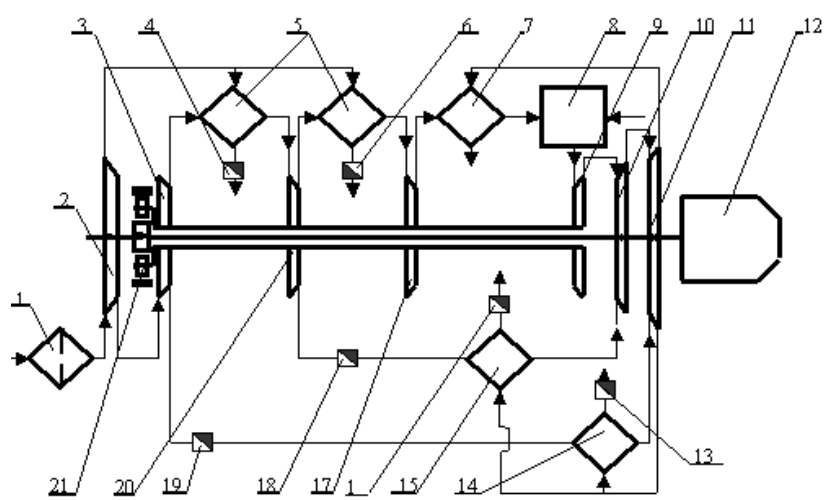

Rys. 2. Schemat silnika turbinowego GTD-7,5 CIAM (7500 $\mathrm{kW})$

1 - filtr; 2 - wentylator chłodzenia powietrza; 3, 17, 20 - sprężarki; 4, 6, 13, 16, 18, 19 - przysłony regulacyjne; 5 - chłodnice powietrza pierwszej i drugiej sprężarki; $7,14,15$ - wymienniki ciepła-podgrzewacze; 8 - komora spalania; 9 - turbina gazo-generatora; 10,11 - turbina prądnicy; 12 - prądnica; 21 reduktor synchronizujący

do drugiego (10) i trzeciego (11) stopnia turbiny. Pozwala to zwiększyć sprawność ST na obciążeniach częściowych. Do sterowania stopniem chłodzenia i przepuszczaniem powietrza przewidziano przysłony regulacyjne $(4,6,13,16,18,19)$.

Podstawowe zespoły tego silnika zostały już opracowane, sprawdzone (zbadane) i wykonane są w metalu. Dopracowania wymagają turbina i wymiennik - podgrzewacz.

Na rys. 3 przedstawiono charakterystyki porównawcze sprawności silników turbinowych i silnika spalinowego. Zastosowanie silnika turbinowego wg obiegu pracy zaproponowanego przez CIAM (krzywa 1, rys. 3) pozwala na znaczne zwiększenie sprawno- 
ści silnika w całym zakresie charakterystyk dławiących.

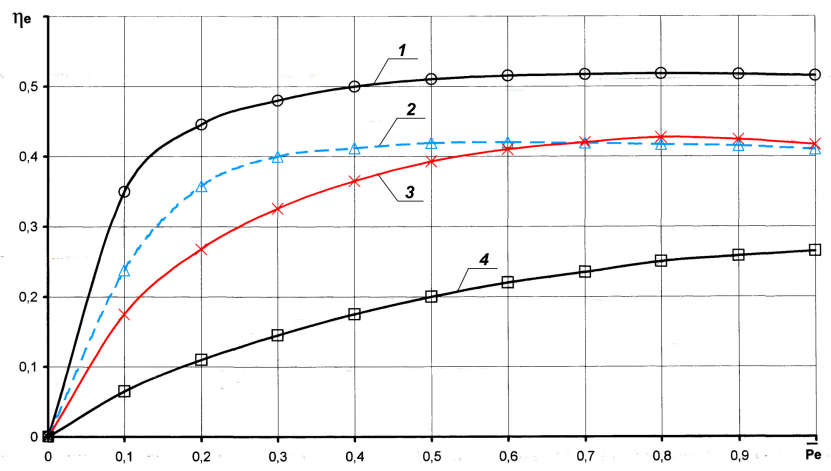

Rys.. 3. Sprawność efektywna silników turbinowych i spalinowych w zależności od względnego ciśnienia użytecznego 1 - ST-7,5 CIAM (7500 kW); 2 - ST1000 - jednostka napędowa lokomotywy manewrowej GEM10 $(1000 \mathrm{~kW}) ; 3$ - silnik spalinowy D49 lokomotywy 2TE70 (3000 kW); 4 - ST HK-361 jednostka napędowa instalacji energetycznej GTE-8.3/HK (8300 $\mathrm{kW}$ ).

Niezmiernie ważnym jest fakt, że w układzie silnika nie przewidziano przekładni redukujących, napędów pomocniczych, prądnicy pomocniczej, urządzenia rozruchowego itp., w sposób znaczący wpływających na cenę, niezawodność i koszty wyposażenia.

Uproszczenie układu mechanicznego i zastosowanie międzystopniowego chłodzenia powietrza pozwala w efekcie osiagnąć wysoką niezawodność i trwałość eksploatacyjną silnika. Planowany resurs silnika - 100 tys. motogodz., przebieg do pierwszego przeglądu -25 tys. motogodz.

Dla zapewnienia charakterystyk trakcyjnych lokomotywy koniecznym jest opracowanie prądnicy (12) i przetwornic (falowników), pozwalających na obracanie wałem ST z zasobnika energii, zasilanie silników trakcyjnych, urządzeń pomocniczych, sieci pokładowej i innych układów.

Część postawionych zadań rozwiązywana jest $\mathrm{w}$ trakcie budowy lokomotywy manewrowej GEM10 z silnikiem turbinowym o mocy $1000 \mathrm{~kW}$. Silnik GTD 1000 pracuje na skroplonym gazie ziemnym. ST wyposażony jest $\mathrm{w}$ wymiennik - podgrzewacz i napędza prądnicę synchroniczną. Dzięki zastosowaniu wymiennika ciepła maksymalna sprawność silnika wynosi $42 \%$ przy stosunkowo niskiej temperaturze gazu w komorze spalania 1220K (krzywa 2, rys. 3). Wał silnika i wirnik wysokoobrotowej prądnicy synchronicznej tworzą wspólną konstrukcję, opartą na łożyskach powietrznych i magnetycznych. Prędkość obrotowa prądnicy - $433 \mathrm{1} / \mathrm{s}$ (26000 obr/min).

Układ elektryczny zespołu napędowego przewiduje zasilanie $\mathrm{z}$ jednej prądnicy silników trakcyjnych, silników sprężarek i wentylatorów, rozruch silnika turbinowego z zasobnika energii, zasilanie sieci pokładowej i ładowanie akumulatorów. Przewidziano możliwość przekazania energii do zasobnika i wykorzystanie tej energii przy zmianie warunków pracy trakcyjnej.

Wszystkimi procesami steruje pokładowy sterownik mikroprocesorowy, który realizuje także funkcje kontrolne przed rozruchem i kontroluje stan techniczny układów lokomotywy.

Można przewidzieć pracę silnika turbinowego na skroplonym gazie ziemnym lub na innych rodzajach paliwa. Przejście na jakościowo inną moc nie wymaga wprowadzania zasadniczych modyfikacji w układzie elektrycznym, wymagane są tylko zmiany ilościowe.

Dla dokładnej oceny wskaźników trakcyjnych i energetycznych lokomotyw liniowych z silnikiem turbinowym przeprowadzone zostały porównawcze obliczenia trakcyjne lokomotywy spalinowej 2TE70 i proponowanych do budowy lokomotyw LST2 i LST3 z silnikami turbinowymi.

Na lokomotywie LST2 zaproponowano do realizacji obieg ST z wymiennikiem - podgrzewaczem, bez dodatkowego chłodzenia powietrza. Na perspektywicznej lokomotywie LST3 dzięki zastosowaniu wtrysku wody zainstalowana moc jest o $25 \%$ mniejsza, niż na lokomotywie LST2. Oprócz tego, na tej lokomotywie należy realizować obieg pracy ST wg propozycji CIAM.

Porównanie charakterystyk technicznych tych lokomotyw zestawiono w tablicy 1 . Masa pociagu była wybierana $\mathrm{z}$ uwzględnieniem warunków przejazdu składu na wybranym odcinku linii kolejowej, no nie większy niż $6000 \mathrm{Mg}$. Wyniki obliczeń trakcyjnych przedstawiono w tablicy 2 .

Wyprodukowanie silnika turbinowego dla lokomotyw pozwoli zbudować lokomotywy LST2 i LST3 ze wskaźnikami, znacznie przewyższającymi analogiczne parametry współczesnych lokomotyw spalinowych: odnośnie zużycia paliwa - o 1,1 -1,3 razy (tabl. 2), kosztów eksploatacji - o 30 - 40\% i wskaźników ekologicznych - o 10-15 razy.

Niezmiernie interesującym jest zastosowanie współczesnych silników turbinowych do lokomotyw pasażerskich i manewrowych. Sprzyjające wskaźniki dotyczące ciężaru i wymiarów gabarytowych silników turbinowych pozwalają zbudować środki transportu, łączące właściwości pojazdów elektrycznych i autonomicznych.

W najbliższym dziesięcioleciu pojawią się na świecie $\mathrm{w}$ transporcie kolejowym seryjnie produkowane autonomiczne lokomotywy z silnikami turbinowymi. 
Tablica 1

Przyjęte do obliczeń trakcyjnych i energetycznych charakterystyki lokomotyw 2TE70, LST1, LST2, LST3

\begin{tabular}{|c|l|ccc|c|}
\hline Lp. & \multicolumn{1}{|c|}{ Nazwa } & 2TE70 & LST1 & LST2 & LST3 \\
\hline 1 & Zainstalowana moc jednostki napędowej, kW & 6000 & 8200 & 6000 & 4500 \\
\hline 2 & Moc lokomotywy godzinna, kW & 6000 & 7000 & 6000 & 6000 \\
\hline 3 & Moc na cele trakcyjne godzinna, kW & 4680 & 5600 & 4900 & 4900 \\
\hline 4 & Ilość osi & 12 & 12 & 16 & 16 \\
\hline 5 & Masa, Mg & 282 & 300 & 376 & 376 \\
\hline 6 & Nacisk zestawu na tor, kN & 230 & 245 & 230 & 230 \\
\hline 7 & Siła pociągowa przy prędkości ciagłej, kN & 600 & 427 & 1040 & 1040 \\
\hline 8 & Prędkość ciagła, m/s (km/h) & $7,8(28)$ & $13,1(47)$ & $4,7(17)$ & $4,7(17)$ \\
\hline 9 & Maksymalna sprawność jednostki napędowej & 0,43 & 0,26 & 0,46 & 0,56 \\
\hline 10 & Sprawność lokomotywy & 0,34 & 0,21 & 0,38 & 0,46 \\
\hline 11 & Godzinowe zużycie paliwa, kg/h & 1170 & 1980 & 960 & 786 \\
\hline 12 & Zużycie paliwa na biegu jałowym, kg/h & 32 & 400 & 96 & 80 \\
\hline
\end{tabular}

Tablica 2

Porównanie wskaźników lokomotywy spalinowej 2 TE70 i lokomotyw z silnikami turbinowymi LST1, LST2, LST3 (na podstawie wyników obliczeń trakcyjnych na odcinkach linii kolejowych)

\begin{tabular}{|c|c|c|c|c|c|c|c|c|}
\hline \multirow{2}{*}{$\begin{array}{c}\text { Typ lokomo- } \\
\text { tywy i moc, } \\
\text { kW }\end{array}$} & \multirow{2}{*}{ 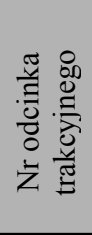 } & \multirow{2}{*}{$\begin{array}{c}\begin{array}{c}\text { Masa } \\
\text { pociagu }\end{array} \\
\text { Mg }\end{array}$} & \multicolumn{2}{|c|}{ Prędkość } & \multicolumn{2}{|c|}{$\begin{array}{c}\text { Jednostkowe zużycie } \\
\text { paliwa }\end{array}$} & \multicolumn{2}{|c|}{$\begin{array}{c}\text { Cena paliwa za prze- } \\
\text { jazd }\end{array}$} \\
\hline & & & $\underset{\mathrm{km} / \mathrm{h}}{\operatorname{minimalna}}$ & $\begin{array}{l}\text { średnia } \\
\text { techniczna, } \\
\mathrm{km} / \mathrm{h}\end{array}$ & $\mathrm{kg} / 10^{4} \mathrm{btkm}$ & $\begin{array}{l}: 0 \\
0 \\
0 \\
\Xi \\
0 \\
\underline{\Xi}\end{array}$ & Z & $\begin{array}{l}: 0 \\
0 \\
0 \\
\vdots \\
0 \\
\underline{\Xi}\end{array}$ \\
\hline \multirow{3}{*}{$\begin{array}{l}2 \text { TE70, } \\
2 * 3000\end{array}$} & 1 & 6000 & 25,0 & 47.0 & 16.1 & 1.0 & 7293,4 & 1.00 \\
\hline & 2 & 2900 & 28.0 & 48.3 & 27.2 & 1.0 & 3427,6 & 1.00 \\
\hline & 3 & 6000 & 36,2 & 47.0 & 12.3 & 1.0 & 8988,2 & 1.00 \\
\hline \multirow{3}{*}{$\begin{array}{l}\text { LST1, } \\
7000\end{array}$} & 1 & 6000 & 28.0 & 47.1 & 33.2 & 2.06 & 9483,8 & 1.30 \\
\hline & 2 & 3000 & 32.0 & 49.5 & 60.1 & 2.21 & 4938,3 & 1.44 \\
\hline & 3 & 6000 & 39.8 & 47.0 & 29.3 & 2.38 & 13558,6 & 1.51 \\
\hline \multirow{3}{*}{$\begin{array}{l}\text { LST2, } \\
6000\end{array}$} & 1 & 6000 & 24.3 & 47.2 & 14.9 & 0.93 & 4270,1 & 0.58 \\
\hline & 2 & 4200 & 18.0 & 48.4 & 23.8 & 0.87 & 2739,5 & 0.80 \\
\hline & 3 & 6000 & 36.3 & 47.0 & 12.3 & 1.00 & 5738,7 & 0.63 \\
\hline \multirow{3}{*}{$\begin{array}{l}\text { LST3, } \\
6000\end{array}$} & 1 & 6000 & 24.3 & 47.0 & 12.3 & 0.76 & 3514,2 & 0.48 \\
\hline & 2 & 4200 & 18.0 & 48.4 & 19.6 & 0.72 & 2253,3 & 0.66 \\
\hline & 3 & 6000 & 36.3 & 47.2 & 10.2 & 0.83 & 4726,3 & 0.52 \\
\hline
\end{tabular}

1. Odcinek trakcyjny - długość $429 \mathrm{~km}$, maksymalne wzniesienie $18,3 \%$ o.

2. Odcinek trakcyjny - długość $247 \mathrm{~km}$, maksymalne wzniesienie $25,0 \%$ o.

3. Odcinek trakcyjny - długość $692 \mathrm{~km}$, maksymalne wzniesienie 9,4\%o.

\section{Literatura}

[1] Коссов Евгений: Газотурбовоз: будет ли место? Под солнцем ли? РЖД-Партнер. №6(130) 2008. 